\title{
WRITING THEMSELVES INTO \\ EXISTENCE: The Intersection of History and Literature in Writings on Black Women
}

\author{
Noliwe Rooks
}

IN THE PAST five years, a few scholars have begun to devote their time to the frustrating but rewarding task of recovering Black women's historical lives. Their jobs have been made frustrating by the studied silences which have cloaked Black women's lives and make research almost impossible; but at the same time it is rewarding, for it offers an opportunity to write a full picture of Black women into history.

Few people who study Black women fail to note that they suffer a double oppression: that shared by all Blacks, and that shared by most women. One consequence of this double jeopardy has been the Black woman's virtual invisibility in the majority of American historical scholarship. Much of what is important to Blacks is not visible to whites, and much of what is important to women is not visible to men. To both groups, the Black slave woman is important only when her activities somehow involve them.

Relatively recently, Black women writers of fiction have begun to reclaim and reconstruct Black womanhood during slavery. Their writings oftentimes differ in fundamental ways from the findings of "scholars." What I am interested in here is the dialogue between the scholarly writings which focus on slavery, the slave narratives of Black women, and Black women writers' fictional accounts of Black womanhood during that period. While the three parts of this discussion would seem to be quite different, they all add something to our knowledge of Black women during slavery; indeed they are three distinct voices in a continuing dialogue on the Black woman's life during that period.

In the scholarly voice, we hear the manner in which Black women have been perceived by men; because one could argue that percep- 
tions constitute reality, it is important to understand how men (white and Black) have perceived Black women. From the autobiographical voice, we hear Black women's perception of themselves which, while arguably shaped by white perceptions as well as male perceptions, is still distinct. And finally from the fiction of Black women writers we hear the perceptions of twentieth-century Black women writers who have begun to meditate on the thoughts, feelings and ideas of Black women in a community of slaves.

The importance of reconstructing Black women's lives and histories is rooted, not only in an understanding that we have a responsibility to write a history which does not exclude an entire portion of the world, but also in knowing that until we do we have not been correct, true, or honest in our scholarly endeavors. This, then, is an exploration of the ways in which the life of the Black slave woman has been portrayed in history and literature.

Despite the wealth of information we now have about slavery, few scholars have dealt realistically with the lives of Black women. ${ }^{1}$ I would agree with Deborah White's argument that the major reason for our lack of knowledge has to do with the way the scholarly debate among historians has been shaped.

During the 1960's and 1970's, Stanley Elkins began an argument as to the nature of the Black slave personality when he alleged that the American slave master had such absolute power and authority that the slaves were reduced to a childlike dependency, or, put another way, developed a Sambo personality. This personality was produced by the slaves' limited contact with positive role models. This thesis had a great effect upon the research and writing of the history of slavery. Indeed, it spawned research that otherwise might not have been undertaken. ${ }^{2}$ The direction the research took, however, was in large part predetermined because, as White points out, Elkins' Slavery defined the parameters of the debate as male.

Elkins maintained that slave women, as opposed to being "Sambos," were allowed the alternative role of mother:

The mother's own role loomed far larger for the slave child than did that of the father. She controlled those few activities-household care, preparation of food, and rearing of children-that were left to the slave family. (Elkins 130) ${ }^{3}$

Since Elkins' Sambo theory rested, in part, on the absence of significant roles for the slave to play, to recognize the role of mother was tantamount to arguing that Black women escaped "samboism."

Another reason for arguing that Black women eluded the label of "Sambo" would have to be Sambo's corresponding stereotype, mammy. Whatever we now think of this as an image, she was 
considered a role model for both whites and Blacks at the time. Finally, one could argue that Black women escaped samboism because no one expected women to be assertive or aggressive. For centuries women had been characterized and in fact rewarded for being childlike and docile.

Humility was seen as a mark of class in a woman, and weakness an indication of grace (White 20). The characterization of the slaves as Sambos, then, was clearly directed at men, as the qualities it embodied were those that all females, regardless of race, were taught to strive toward.

The emphasis of much of the literature which Blacks have produced on slavery has been on refuting the idea of Samboism by adding to our knowledge of the father's role in the slave community, as well as the male role under slavery in general. The result has been to restore the male slave's masculinity while basically ignoring the lives of Black women.

This is the historical space within which the "discovery" of the slave narrative took place. It was time, scholars felt, to let the slaves tell their own stories and to use them as historical documents. Black women, however, did not fare any better during this period than they had in the past; here they came to be viewed solely as sexual victims. There seem to be at least two major reasons for this characterization. The first would be the historical fact that Black women were brutalized during this period; the second reason would be the slave narrative.

Widely accepted as being, if not the slave's own true story, at least the version the most sympathetic to the slaves, most narratives stereotyped slave women as sexually exploited beings. Most slave narratives, however, were related by men. Narratives by slave women present a significantly different perception of slavery. It is this discrepancy which has not been duly noted, and it is this neglect of slave women's versions of their lives that is a basic reason for the perpetuation of the image of women slaves solely as victims.

A close look at male slave narratives would lead one to believe that Black men shared the nineteenth century's inclination for defining women in terms of manners and morals. An example of the treatment given slave women by male narrators is the description by William Craft, who implies that for the woman, rape or seduction is virtually inevitable:

It is a common practice for gentlemen (if I may call them such), moving in the highest circles of society, to be the fathers of children by their slaves, whom they can and do sell with impunity.... Oh! if there is any one thing under the wide canopy of heaven horrible enough to stir a man's soul, and to make his very blood boil, it is the thought of his dear wife, his unprotected sister, or his young and 
virtuous daughters, struggling to save themselves from falling a prey to such demons! (274-75)

Craft's comment that the indignities to which these defenseless women are subjected are enough to make a man's blood boil is certainly not intended to belittle the brutal effect upon the women, but it does remind us that maltreatment of women is often considered an affront to the men with whom the women are associated. ${ }^{4}$

The male slave narrators are also careful to blame the lust and greed of white men for these situations. Henry Bibb, among others, claims it is this obscenity which sustains the institution of slavery:

The strongest reason why southerners stick with such tenacity to their "peculiar institution," is because licentious white men could not carry out their wicked purposes among the defenseless colored population as they do without being exposed and punished by law, if slavery was abolished. Female virtue could not be trampled under foot with impunity, and marriage among the people of color kept in utter obscurity. (169)

In narrative after narrative by male slaves, graphic portrayals of sexual abuse of slave women by white men abound. (Rare indeed is any reference to sexual abuse of slave men by white women, and homosexuality is never mentioned in the works that I have looked at.) The effect is a monolithic characterization of slave women as utter victim.

When slave women tell their stories, however, they barely mention sexual experiences and neither rape nor seduction is presented as the most profound aspect of their existence. Though they document the trauma involved in sexual exploitation, the slave women's works do not center solely around this event. While Black women wrote to witness slavery's atrocities, they also wrote to celebrate their hard-won escape from that system.

The switch in characterization of slave women from passive to active in their narratives, is partly due to the fact that they are protagonists and therefore expected to exhibit more complex traits and to engage in a greater variety of experiences than when all women are secondary characters. However, slave women's narratives also present more positive images of secondary female characters, devote more discussion to family relationships, and rely less upon litanies of beatings and mutilations of other slaves. This seems to indicate a subtle difference in the values of male and female slave narrators. Male narrators interpret that which they saw and deemed significant of other slaves' experiences as a means of enhancing their descriptions of the crippling power of slavery. Rather than elaborating upon the weight of their oppression, the women emphasize the sources of the strength with which they met that force. As an example, let us look at the ways female narrators treat sexual harassment by comparing the earlier 
cited statements by William Craft and Henry Bibb concerning the perils of slave women and Harriet Jacobs's and Elizabeth Keckley's analysis of their own experiences.

Jacobs was fifteen when she became sexually active. When she entered a liaison with a white man, it was not the effect upon her male relatives that she chronicled, but instead her grandmother's response. When her grandmother discovered the affair, she exclaimed, "I had rather see you dead than to see you as you now are. You are a disgrace to your dead mother." Tearing her mother's wedding ring from Jacob's hand, her grandmother proclaimed, "Go away! and never come to my house again" (387).

This rather extreme reaction shows that such conduct was not so common as to be easily excused by other slave women. Though later grandmother and granddaughter were reconciled, Jacobs reports that her grandmother "did not say, 'I forgive you," but that "she looked at me lovingly with her eyes full of tears. She laid her old hand on my head and murmured, 'Poor child! Poor child!'” (388).

Though Harriet Jacobs was driven to desperation by her master, by her own account she was not completely defenseless. She was not seized, beaten, and raped. Jacobs was propositioned for several months by her master, who occasionally threatened but more often begged, pleaded, and coaxed. He sent notes and gifts and eventually began to build her a small house in the woods as a bribe for her consent. Rather than the object of physical violence, Jacobs merely describes herself as a person confronted with a dilemma.

Because her master had denied her request to marry a Black suitor, she decided to revenge herself. She chose to become the mistress of an unmarried professional man:

To be an object of interest to a man who is not married, and who is not her master is agreeable to the pride and feelings of a slave, if her miserable situation has left her any pride or sentiment. It seems less degrading to give one's self, than to submit to compulsion. There is something akin to freedom in having a lover who has no control over you, except that which he gains by kindness and attachment. (385)

Sexual exploitation of slave women is verified by Harriet Jacobs in her narrative. In spite of her exposure to it, she was able to exercise some control over her situation. In exchange for sexual favors, she gained two children and protection from the advances of her master. While Jacobs does document her sufferings and brutal treatment, she does so in a context that is also the story of resistance.

This resistance is illustrated by the fact that sex was but one aspect of her life. These incidents are covered in a relatively brief portion, near the beginning of her work. The emphasis of Jacob's narrative is upon her attempts to win freedom for herself and her children, her seven years of hiding in an attic, her dangerous escape to freedom, 
her success in finding jobs, and the reunion of her family in the North. Her self-esteem was so strong that as a fugitive slave she rejected all efforts to legalize her freedom by paying her master's price. When she received word that her manumission had been purchased, she wrote one of her benefactors:

I thank you for your kind expressions in regard to my freedom; but the freedom I had before the money was paid was dearer to me. God gave me that freedom; but man put God's image in the scales with the paltry sum of three hundred dollars. . . . (509)

The narrative of Elizabeth Keckley is similar to that of Jacobs in that it also places her sexual victimization in the context of resistance. Indeed, her victimization is covered in only one paragraph near the beginning of the work:

I was regarded as fair-looking for one of my race, and for four years a white man-I spare the world his name-had base designs upon me. I do not care to dwell upon the subject, for it is one that is fraught with pain. Suffice it to say that he persecuted me for four years, and I-I-became a mother. . . .

Keckley's brief acknowledgement of her sexual persecution seems to be more typical of female narratives than that by Harriet Jacobs, but like Jacobs's it is less an admission of frailty than it is an attack upon a society that condones such an atmosphere within which some women must live.

While sexual exploitation is included in Keckley's autobiography, she is far more interested in describing her success as a modiste and her reputation as a professional for whose services the ladies in society competed and of whose friendship Mrs. Jefferson Davis and Mrs. Abraham Lincoln boasted.

Female slave narratives do, however, spend a considerable amount of time and space describing the relationship between Black women and their white mistresses. In a chapter titled, "The Trials of Girlhood," Jacobs notes that "the degradation, the wrongs, the vices, that grow out of slavery, are more than I can describe. They are greater than you would willingly believe." She goes on to say that the slave children become "prematurely knowing in evil things" (350), but she indicts not only the slave-holding men, but also the slave mistresses.

Jacobs understood the predicament of Southern white women, yet she criticized them for having so little compassion toward their women slaves. Jacobs, through no fault of her own, was caught in a three-way love affair with her master and mistress. When her master would make sexual overtures toward her, her mistress, imagining the worst, would abuse Jacobs. Jacobs yearned for some show of sympathy from her mistress. As she put it, "one word of kindness from her would have brought me to her feet." The kindness, however, was never forthcoming. 
Keckley, like Jacobs, also spends a fair amount of time discussing the cruelty she suffered at the hands of her white mistress. Keckley recalls the vindictiveness of a mistress who, feeling that the slave woman was too proud, persuaded a man to whip her. Shortly after her day's work had ended, the man called Keckley into his study and told her to take down her dress, as he was going to whip her. Keckley says:

Recollect, I was eighteen years of age, was a woman fully developed and yet this man cooley bade me take down my dress. I drew myself up proudly, firmly, and said: "No, Mr. Bingham, I shall not take down my dress before you. Moreover, you shall not whip me unless you prove the stronger." (33)

Keckley's tormenter overpowered her and proceeded with the beating. This, however, was not enough to satisfy the slave mistress and the beatings continued for several weeks. Keckley tells how she fought back, biting and kicking and chastising the man for his cruelty until finally he "burst into tears, and declared that it would be a sin to beat me any more" (37).

Another example of the differences between male and female slave narratives can be seen in Annie Louise Burton's portrayal of her maternal heritage. An argument with her mistress resulted in Burton's mother's first whipping. The event so enraged her mother that she ran away and was not heard from for three years. When she returned, the Civil War had just ended. Her mistress refused to release her children, so the mother kidnapped Annie and her siblings. When two men appeared at Burton's mother's door, demanding the return of the children, the woman not only refused, but threatened to enlist the aid of the Union soldiers. Says Burton, "the young men left and troubled us no more" $(100)^{5}$

Obviously not all slave women distinguished themselves as did these cited here, and it was not my intention or the intention of the slave women narrators to imply that such was the case. Nor is there any reason to believe that slave women tried to suggest that they were any more heroic than slave men or that they tried to diminish the intensity of suffering and pain that can result from sexual exploitation. The narratives of the women do, however, give us a broader picture of Black women under slavery than we have had before.

The number of slave narratives published by men far exceeds the portrayals of women, and thus the slaves self-portrayal is dominated by male features. Male narrators' use of slave women's experiences was limited by the conventions of the slave narrative as well as by their conventional nineteenth-century male notions of woman's place. As a result, slave women were stereotyped as sexual victims.

Women narrators, because of their convictions and those same generic conventions and the differing view of woman's place, present stronger, more complex portraitures of their sex, which deserve to be 
included as the history of slavery goes through any future rewritings. Because, as H.L. Gates writes:

No written text is a transparent rendering of "historical reality," be that text composed by master or slave. The slave's narrative has precisely the identical "documentary" status as does any other written account of slavery. Whereas its presuppositions tend to differ dramatically from those of texts written by nonslaves, both sets of texts are of the same order as historical documents and literary discourse. (Davis and Gates xi)

Black women writers of fiction agree with the necessity of including Black women's voices in the dialogue which shapes history. Margaret Walker Alexander and Sherley Anne Williams are two women who have begun to claim a space in history where Black women's lives are in their control. Williams writes:

Afro-Americans, having survived by word of mouth - and made of that process a high art-remain at the mercy of literature and writing; often these have betrayed us. I loved history as a child, until some clear-eyed young Negro pointed out, quite rightly, that there was no place in the American past I could go and be free.... This novel, then, is fiction. . . A And what is here is as true as if I myself had lived it. Maybe it is only a metaphor, but I now own a summer in the 19 th century. . . .

Black women, as has been discussed, still remain at the "mercy of literature and writing" for the simple reason that they have rarely written their own stories. The slave narrative was the first genre which offered that sort of self-creation, and the influence of the slave narrative is obvious in Margaret Walker Alexander's first novel, Jubilee. What is also apparent is a commitment to the same issues that female slave narratives addressed. Walker writes that she had:

The most valuable slave narrative of all, the living account of my greatgrandmother, which has been transmitted to me by her own daughter. I knew then that I had a precious, almost priceless, living document of my own. (How I Wrote Jubilee, 18)

Jubilee, therefore, emerges from the tradition of the slave narrative, and Walker uses the research into this unique Afro-American literary genre to support the oral tradition of the Black family out of which the idea of her novel comes. The life of Vyry, her husbands-Randall Ware and Innis Brown-and her children, was handed down by one of those children to Walker, an artist who would finally make of the tale a Jubilee, a celebration of freedom and restoration. The novel joins the nineteenth and twentieth centuries together, as well as the oral and written traditions of Afro-Americans.

This process of handing down a story is not new. Every family has a history which is passed from one generation to the next. Walker, however, in committing her family's history to novel form also gives a past to many unnamed slave women. The form her story takes is important as novels usually allow more people access than do schol- 
arly works. Walker understands that the role of the novelist is not necessarily as removed from the role of the historian as we may have been led to think. Indeed she believes

that the role of the novelist can be, and largely is ... the role of a historian. More people will read fiction than will history, and history is slanted just as fiction may seem to be. People will learn about a time and a place through a historical novel. ("Poetry" 10)

Jubilee is Vyry's story; she is at the center of the novel, and until its publication in 1966 the story of the Black woman's life during slavery had never been told in fictional form by a Black woman. What is most interesting about the structure of Jubilee is how closely it parallels the experiences of so many slaves in bondage, as well as demonstrating how the condition of being a female effectively limited the opportunity of many Black women to escape to freedom.

Women were less mobile than men. Not only were they required to carry out the master's orders in the field or in the "big house" during the day, but they were often forced to be accessible in order to minister to the master's nocturnal needs.

Vyry's mother, Sis Hetta, was given to young master John Dutton when she was "barely more than a pickaninny." She died when she was 29, after having given birth to fifteen children. Yet in spite of her deathbed agony, as a result of another childbirth-and the loss of previous children-Hetta does not want to die without seeing her child, Vyry. The deep concern and attachment slave women had for their children may explain in part why they were less apt to become fugitives.

Walker hits on this same point when she describes Vyry's attempt to escape via the underground railroad. Vyry dresses in the male clothing that her lover, Randall Ware, has provided for her and starts for the swamp to meet him. While Randall has convinced her that her children will follow her to Canada at a later date, when the baby, Minna, begins to cry and wakes up her brother, Jim, Vyry can not bear to leave them and takes them along. Vyry tries to follow the instructions that she has been given, but she does not have Randall's experiences out in the world, is not literate, does not understand what the underground railroad is and has no confidence that if she leaves her children, she will ever see them again. Needless to say, Vyry and her children do not get to the swamp. She is captured, taken back to the plantation and beaten.

The fact that Walker chooses to include these incidents may not seem at all significant upon first examination, but when looked at in the light of the newly emerging scholarship on the subject, her inclusion of these facts takes on a different meaning.

According to Deborah White, some of the reasons why women were 
under-represented in the fugitive slave population had to do with childbearing. Most runaways, White believes, were between sixteen and thirty-five years old. More than likely a woman that age was either pregnant, nursing an infant, or had at least one small child to care for. While we may assume that fugitive males loved their children, the slave woman who left her children behind could not be certain that they would receive the best possible care (70).

The hold children could place on their mothers is obvious from Harriet Jacobs's narrative. For years the Flint family's hold upon Jacobs's children kept her from fleeing. Indeed she preferred living in a cramped attic space for seven years to taking her freedom without her children. She explained, "I was certain my children were to be put in their power, in order to give them a stronger hold on me" (67).

One of the most important reasons for the difference between male and female slavery would appear to have been the slave woman's childbearing and child care responsibilities. These effected the female slave's pattern of resistance in that they may not have been able to take advantage of many of the opportunities they may have had to escape. Motherhood, then, would seem to have taken on a different significance and represented a different kind of confinement than it did for white women as it anchored slave women more firmly to the plantation.

Walker's novel focuses on the differences between male and female slavery. While no "scholarship" on Black female slavery existed in 1942 when Walker began this work, she was able to construct an existence for her characters which was substantially different from the prevailing constructions of history, but which has been proven to be valid. She has then, in effect, revised and rewritten the predominantly white male discourse on slavery by writing herself into existence. Her methodology was not difficult; she had listened to her grandmother's bedtime stories and therefore knew that there was a "herstory" to be told which was in conflict with the history she had been taught.

It is this same "betrayal" of history to adequately explore Black women's past which also led Sherley Anne Williams to invent a history for herself. Dessa Rose, according to Wiliams, is based on two historical incidents. The first had to do with a Black woman who in 1829 helped to lead an uprising on a coffle in Kentucky. Caught and convicted, she was sentenced to death; her hanging, however, was delayed until after the birth of her baby. The second incident happened in North Carolina in 1830. A white woman living on an isolated farm was reported to have given sanctuary to runaway slaves. Williams simply wanted to find out what would have happened if these two women had ever met (5). 
The structure of Dessa Rose is in itself a critique of the lack of Black women's voice within history. The first section is titled "The Darky" and consists of the journal entries of a white amanuensis regarding the "crazy Black wench" he is including in his book on the slave personality. The final two chapters are Dessa's voice. Williams seems to suggest that the importance of revising Dessa Rose so that Dessa's voice is the only voice, lies not only in the fact that it is her story and her history, but also in the fact that history has rarely if ever allowed that voice to be heard.

The first chapter is dominated by a white investigator and his perceptions of Black life that he cannot possibly understand, just as the first chapters of Black women's lives have been dominated by a white male voice which has not been willing to grant Black women a separate humanity. When Dessa escapes and reclaims her life, we are allowed to hear her "truths" without the stereotypes the white investigator included in his, and are thereby treated to a view of history that is, for the most part, new and different from those that the white narrator exposes us to.

The way Williams chooses to have Dessa tell her story is also indicative of one of the ways history has always been passed around by women in the Black community. Dessa is braiding a child's hair and "remembering" her life. She says,

Child learn a lot of things setting between some grown person's legs, listening at grown peoples speak over they heads. This is where I first learned to listen, right between mammy's thighs, where I first learned to speak, from listening at grown peoples talk. ... (234)

Children who are taught "between some grown person's legs" learn more than just how to listen and how to speak. They also learn a way of looking at the world-a way of centering their experiences in opposition to those of the "dominant culture."

An example of the differences between Dessa and the white narrator can be seen in the way he hears Dessa retelling the story of the coffle killings. Whenever he would ask a question about their activities, Dessa would respond by talking about her relationship with Kaine. When Kaine's master kills him, Dessa responds by trying to kill the master. When she fails, she is sold to a coffle. Midway through their trip, Dessa and the other slaves overpower the white men and all but Dessa escape. While the white interviewer cannot understand why Dessa, who was visibly pregnant at the time, would fight so hard to kill her oppressors, we, the readers, hearing the story through Dessa's voice as we "sit between her legs," have no problem understanding at all.

Dessa was fighting so that her child could have the chance to be born free. And since Kaine introduces the concept of freedom to 
Dessa, he is at the center of her story. The white interviewer, however, has no context for understanding Dessa's story as he has never been taught to listen. It does not serve his interest to do so.

The fact that Dessa makes a point of saying that she misses the way women used to get together to braid their children's hair, points to a communal experience which Black women shared that was important to their day-to-day lives. This statement also signals the practice of Black women getting together to support and nurture one another during slavery.

Slave women have often been characterized as self-reliant and self-sufficient because they had to develop their own means of resistance and survival. The strength to be self-reliant and sufficient, however, had to be cultivated. It came no more naturally to them than to anyone, slave or free, male or female, black or white. If they seemed exceptionally strong it was partly because they often functioned in groups and derived strength from their numbers.

Historians have shown that the community of the quarters, the slave family, and slave religion shielded the slave from absolute dependence on the master; that parents, siblings, friends, and relatives served in different capacities as buffers against the internalization of infantile roles. The community of women in the slave quarters must have functioned in much the same way, but it may have also done much more.

Treated by Southern whites as if they were anything but selfrespecting women, slave women, it would seem, could forge their own independent definition of womanhood through the female network, a definition to which they could relate on the basis of their own notions about what women should be and how they should act. Williams appears to be pointing out that there must have been some mechanism for defining oneself against the prevailing definitions of womanhood operative during slavery.

Black women writers have begun the task of reshaping and redefining the patriarchy's notions regarding slave women by offering an alternative vision of history-a vision which has Black women at its center. While they have not as yet answered all of the stereotypes of Black women that we have come to accept, they have made a definite start. Their voice, like that of the female slave narrative, does not dwell on sexual victimization, but defines Black women in terms of their ready resistance to such practices. Black women have begun to write themselves into existence. 


\section{NOTES}

1. I should note that Angela Davis in "Reflections on the Black Woman's Role in the Community of Slaves" (Black Scholar December 1971: 3-15) does discuss a number of these issues. She, however, is one of few.

2. One example of this is John Blassingame's The Slave Community (New York: Oxford UP, 1972). Indeed, Blassingame's work is one of the longest and most complete responses to the Elkins book.

3. Angela Davis, however, in her aforementioned work, takes issue with this characterization of the slave woman's place in the community, as does Deborah White.

4. It is also interesting to note that, while Craft's autobiography is entitled ... The Escape of William and Ellen Craft from Slavery, William's is the only voice we hear.

5. There are many short narrations in the Lowenberg book; this one is included to illustrate the range of materials available on Black female slave narratives.

\section{WORKS CITED}

Bibb, Henry. "Narrative of the Life and Adventures of Henry Bibb, an American Slave." Puttin' On Ole Massa. Ed. Gilbert Osofsky. New York: Harper, 1969.

Burton, Annie Louise. "Memories of Childhood's Slavery Days." Black Women in Nineteenth-Century American Life. Ed. Bert Lowenberg and Ruth Bogin. University Park: PA Pennsylvania State UP, 1976.

Craft, William. "Running a Thousand Miles to Freedom, or The Escape of William and Ellen Craft from Slavery." Great Slave Narratives. Ed. Arna Bontemps. Boston: Beacon, 1969.

Davis, Charles T. and Henry Louis Gates, Eds. The Slave's Narrative. New York: Oxford UP, 1985.

Elkins, Stanley. Slavery: A Problem in American Institutional and Intellectual Life. Chicago: U of Chicago P, 1959.

Jacobs, Harriet. Incidents in the Life of a Slave Girl. The Classic Slave Narratives. Ed. Henry Louis Gates Jr. New York: Mentor Books.

Keckley, Elizabeth. Behind the Scenes: Thirty Years a Slave and Four Years in the White House. New York: Arno, 1968.

Walker, Margaret. How I Wrote Jubilee. Chicago: Third World Press.

Walker, Margaret. Jubilee. Boston: Houghton, 1966.

Walker, Margaret. "Poetry, History and Humanism: An Interview with Margaret Walker." Black World. 25 (1975): 10.

White, Deborah Gray. Ar'n't I A Woman?: Female Slaves in the Plantation South. New York: W.W. Norton, 1985.

Williams, Sherley Anne. Dessa Rose. New York: William Morrow. 1986. 